\title{
Fej-nyak régió primer melanomája: irodalmi összefoglaló és öt eset ismertetése
}

\author{
DR. KISS FRUZSINA*, DR. FÜLÖP GÁBOR*, DR. OBERNA FERENC**, DR. BATTYÁNI ZITA*
}

\begin{abstract}
A fej-nyak régió nyálkahártyájának primer melanomája egy ritka és agresszív daganat. A betegséget általában késői stádiumban ismerik fel, melynek oka a betegség gyors, vertikális terjedése, a korai specifikus jelek hiánya és az anatómiai lokalizáció. Primer mucosalis melanoma (PMM) esetén elsődleges terápia a megfelelő sebészi széllel elvégzett radikális rezekció. A radikális nyaki nyirokcsomó-eltávolítás, a sentinel nyirokcsomó-biopszia és a radioterápia alkalmazásának kérdésében még nincs egyértelmú állásfoglalás a szakirodalomban. Mivel nagyon ritka daganattípus, az esettanulmányokból történő információszerzés az adatgyújtés legkézenfekvőbb módja. Cikkünk célja, hogy öt szájüregi lokalizációjú melanomás esetet mutasson be és rövid összefoglalást adjon a betegség etiológiájáról, stagingjéről és terápiás lehetőségeiről az aktuális szakirodalom fényében.
\end{abstract}

Kulcsszó: fej-nyak régió, nyálkahártya melanoma, staging, rezekció

\section{Irodalmi összefoglaló}

\section{Epidemiologia}

A fej-nyak területén lévő nyálkahártya melanoma nagyon ritka előfordulású entitás, a betegség sokkal kisebb valószínűséggel jelenik meg ezen lokalizációban, mint a bőrön, a melanomáknak csak kevesebb mint 1 százalékát alkotja. Míg a bőrön lévő melanomák incidenciája növekszik, a primer nyálkahártya-melanomák előfordulása stagnál. A primer orális lokalizációjú nyálkahártya-melanoma az összes szájüregi malignomák mintegy 0,5 százalékát alkotja, a sinonasalis melanomákkal együtt pedig a fej-nyak tumorok mintegy 4 százalékát [2, 10, 13, 15, 16, 29]. A primer mucosalis melanoma (PMM) fej-nyaki régióban való előfordulása férfiaknál gyakoribb, mint nőknél és 40-70 év között mutatja a legnagyobb prevalenciát [6].

\section{Etiológia, pathogenezis}

Mivel igen nagy ritkaságú daganattípusról beszélünk, pathogeneziséröl viszonylag keveset tudunk, és egyértelmú rizikófaktorait még nem tudták bizonyítani. Lehetséges rizikófaktorok között említik a dohányzást, a rendszeres alkoholfogyasztást és a krónikus irritációt a rosszul illeszkedő fogsor miatt. Leggyakoribb lokalizációja a szájüregben a maxillaris gingiva és a palatum durum [6, 10, 15]. Míg a melanocyták a bőrben protektív szerepet játszanak a napsugárzás káros hatásaival szemben, addig szájnyálkahártyán betöltött szerepük ez idáig ismeretlen. A melanocyták az ectodermából vándorolnak erre a területre az embriogenezis során.
A melanocyták, a naevussejtek és a melanomasejtek egyaránt különböznek citológiai megjelenésükben és biológiai karaktereikben is. A melanomasejtek nagyobbak, mint a naevussejtek, polygonalisak és szabálytalan, megnagyobbodott magjukban a durván rögös kromatin a maghártyához rendeződik [7]. A melanoma kezdetben radiális növekedést mutat, azaz a daganatsejtek intraepidermalisan, horizontális irányban terjednek. Idővel azonban a tumornövekedésben megjelenik a vertikális irány is, ami azt jelenti, hogy a tumorsejtek már a dermális rétegekbe törnek. Szemben a bőrön elöforduló növekedési mintázattal, a mucosalis melanoma esetén, a késői diagnosztizálás miatt, a tumor radiális növekedési fázisával nem találkozunk, hanem már a sokkal agresszívabb nodularis (vertikális növekedési) fázis jelenik meg a submucosa inváziójával együttesen $[7,27]$.

\section{Klinikai paraméterek, diagnózis}

Klinikai megjelenésére jellemző a változékonyág, sötétbarnán, lilán vagy feketén festődő kép, aszimmetrikus, rendezetlen körvonallal. Az esetek 12 százalékában azonban amelanotikus megjelenésú. Felszíne lehet macularis, nodularis vagy kifekélyesedő egyaránt [7]. Tanaka és mtsai. klinikai megjelenés alapján a PMM öt típusát azonosították: a pigmentált nodularis típust, a nem pigmentált nodularis típust, a pigmentált macularis típust, a pigmentált vegyes típust és a nem pigmentált vegyes típust [24]. Tünetei a fájdalom, a kifekélyesedés, a vérzés, a fogvesztés és a csonterózió lehet [7]. 


\section{Staging}

1970-ben Ballantyne írta le a fej-nyak területén lévő primer melanomák egyszerüsített staging rendszerét, melynél az I. stádium a lokalizált lézió, a II. a nyaki nyirokcsomó áttéte, a III. pedig a távoli metasztázis meglétét jelentette. Előnye egyszerüsége mellett az, hogy általánosan, minden melanoma esetén használható. Hátránya, hogy túl nagy hangsúlyt fektet a regionális terjedésre, ami nem túl gyakori PMM esetén, és hogy ezzel ellentétben az invázió mélységére és a lokális tumor terjedésére nem szolgál információval. A legtöbb páciens (75-90\%) I. stádiumban kerül felfedezésre, és ezen rendszer csekély prognosztikai értékkel bír ezen csoport esetén [5, 26]. Ezt kiküszöbölendő, Prasad és munkatársai kidolgozták microstaging rendszerüket, melyben az I. stádiumot az invázió mélysége alapján alcsoportokra osztották (I. táblázat) [13, 15, 21].

\section{1. táblázat}

Klinikai staging rendszer az orális manifesztációjú primer malignus melanomára az első stádium hisztopatológiai microstagingjével kiegészítve

\begin{tabular}{|r|l|}
\hline I. stádium & csak primer tumor $\left(\mathrm{T}_{1,2,3,4}, \mathrm{~N}_{0} \mathrm{M}_{0}\right)$ \\
\hline 1. szint & $\begin{array}{c}\text { in situ melanoma bizonyított invázió nélkül } \\
\text { vagy microinvázióval }\end{array}$ \\
\hline 2. szint & invázió a lamina propriába \\
\hline 3. szint & mély szöveti invázió (izom, csont, porc) \\
\hline II. stádium & regionális nyirokcsomó metasztázis $\left(\mathrm{T}_{1,2,3,4}, \mathrm{~N}_{1} \mathrm{M}_{0}\right)$ \\
\hline III. stádium & távoli metasztázis $\left(\mathrm{T}_{1,2,3,4}, \mathrm{~N}_{1,2,3,4} \mathrm{M}_{1}\right)$ \\
\hline
\end{tabular}

A 2010-ben kiadott AJCC (American Joint Committee on Cancer) Staging Rendszerének 7. kiadása külön fejezetet szentel a fej-nyak területén lévő PMM klasszifikációjának. Ezen rendszer alapján a $T$ jelzés a primer tumor vastagságára és a kifekélyeződés mértékére utal $\left(T_{3}\right.$ : mucosalis kiterjedés, $T_{4 a}$ : közepesen elörehaladott betegség, mély szöveti invázió, porc-, csont-, bőrérintettség, $T_{4 b}$ : nagyon előrehaladott betegség, agy, dura, koponya, IX., X., XI., XII. agyideg, spatiumok, carotis, mediastinum, prevertabralis tér érintettség), az

\section{II. táblázat}

Fej-nyak területén lévő PMM anatómiai stádiumbeosztása és prognosztikus csoportjai

\begin{tabular}{|l|c|c|c|}
\hline Klinikai stádiumok & $\mathbf{T}$ & $\mathbf{N}$ & $\mathbf{M}$ \\
\hline III. & $\mathrm{T}_{3}$ & $\mathrm{~N}_{0}$ & $\mathrm{M}_{0}$ \\
\hline IV.A & $\mathrm{T}_{4 \mathrm{a}}$ & $\mathrm{N}_{0}$ & $\mathrm{M}_{0}$ \\
\hline & $\mathrm{T}_{3}-\mathrm{T}_{4 \mathrm{a}}$ & $\mathrm{N}_{1}$ & $\mathrm{M}_{0}$ \\
\hline IV. $\boldsymbol{B}$ & $\mathrm{T}_{4 \mathrm{~b}}$ & $\mathrm{~N}_{0,1}$ & $\mathrm{M}_{0}$ \\
\hline IV. $\mathbf{C}$ & $\mathrm{T}_{1,2,3,4}$ & $\mathrm{~N}_{0,1}$ & $\mathrm{M}_{1}$ \\
\hline
\end{tabular}

$\mathrm{N}$ jelzés a regionális nyirokcsomó áttéteket jelenti $\left(\mathrm{N}_{0}\right.$ : nincs regionális nyirokcsomó metasztázis, $\mathrm{N}_{1}$ : van regionális nyirokcsomó metasztázis), míg az $\mathrm{M}$ a távoli metasztázisokra és a szérum laktát- dehidrogenáz szintjére ad iránymutatást $\left(M_{0}\right.$ : nincs távoli metasztázis, $M_{1}$ : van távoli metasztázis). Az új staging rendszer a $T_{3}$ stádiummal kezdődik, rávilágítva ezzel a fej-nyak területén lévő PMM agresszív természetére (II. táblázat) [2, 6].

\section{Terápia}

PMM esetén elsődleges terápia a megfelelő sebészi széllel elvégzett radikális rezekció. Az adekvát terápia ellenére azonban gyakori a lokális kiújulás. Ez esetben egyidejúleg már távoli metasztázisok megjelenése is gyakori, ezért újbóli rezekció előtt ismételt staging szükséges. Amennyiben nem mutatható ki távoli metasztázis, ismételt sebészi eltávolítás javasolt, ha a tumor megfelelő sebészi széllel eltávolítható $[5,19]$.

A sentinel nyirokcsomó-biopszia szerepe nyálkahártya-melanoma esetén még tisztázatlan, azonban a bőrről kiinduló daganatok bizonyos eseteiben kötelező elvégezni. Az kétségkívüli, hogy a betegség stagingjére hasznos információkat ad, de a betegség kimenetelét befolyásoló terápiás szerepe egyelőre megkérdőjelezhető [11, 19, 31], azonban egyes szerzők ez esetben is potenciálisan hasznosnak írják le [23].

A radikális nyaki nyirokcsomó-eltávolítás kérdésében nincs egyértelmű állásfoglalás a szakirodalomban. Egyes szerzők szerint PMM esetén nincs szignifikáns különbség az 5 éves túlélésben a nyaki nyirokcsomók eltávolítása és helyben hagyása esetén, ezért ez esetben a nyaki nyirokcsomók agresszív eltávolítása alaposan mérlegelendő. Nyaki nyirokcsomó-eltávolítás javasolt azonban, ha a lymphadenopathia klinikailag megjelenik és tüneteket mutat $[18,28]$. Egyes tanulmányok profilaktikus céllal nem javasolnak radikális nyaki disszekciót [25], azonban orális lokalizáció esetén potenciálisan előnyösnek írják le a profilaktikus nyaki disszekciót, a nagyszámú nyirokcsomó metasztázis és a helyi kiújulás nagy veszélye miatt $[9,14,18]$.

A National Comprehensive Cancer Network legújabb, 2013-as ajánlása alapján több szempontot kell figyelembe venni. Ilyenek a nyirokcsomóáttétek, mely alapján cNO melanoma esetén szoros obszervációt, CLN pozitív esetben azonban radikális nyaki dis $\left(\mathrm{T}_{3}\right.$ szekciót javasolnak $[18,28]$. A klinikai típus és a lézió mérete szintén szempontként jelenik meg az ajánlásban, a nodularis típusú de cNO pácienseknél profilaktikus nyaki disszekció javasolt, míg cNO macularis típusú, de 4 cmnél kisebb daganat esetén elég az obszerváció [18].

A sugárterápia kérdése szintén ellentmondásos a szakirodalomban. Egyes tanulmányok szerint a sugárterápia effektív [26], míg mások szerint az orális manifesztációjú melanoma nem érzékeny sugárkezelésre [28]. A posztoperatív radioterápia szóba jöhet olyan páciensek esetén, akik PMM-ja nagy kiterjedésú és olyan helyen található (pl. paranasalis sinusok), ahonnan in toto exstirpatiója nehézségekbe ütközik. Nyirokcsomó 


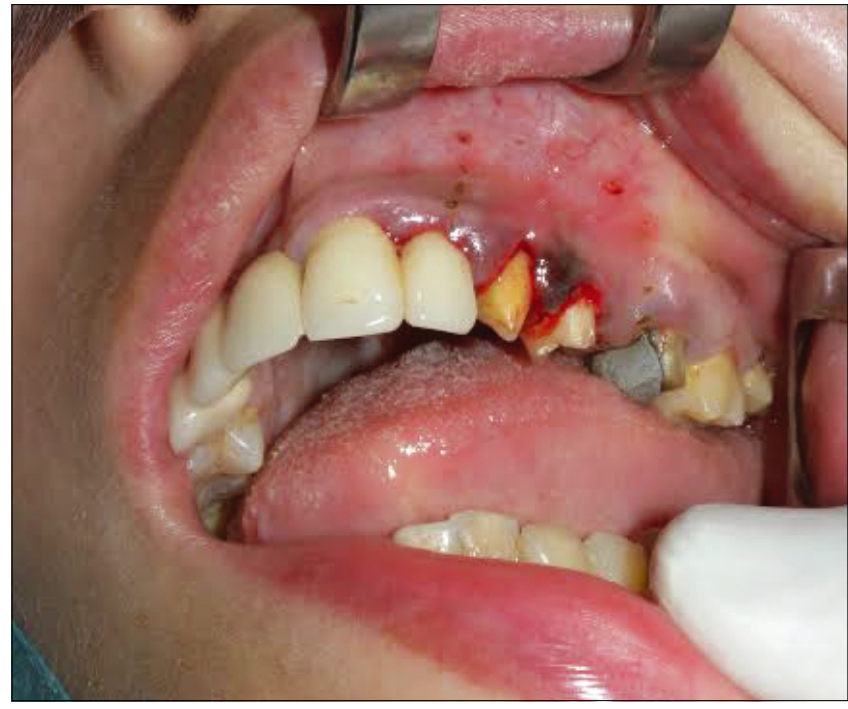

1. kép: Bal felső szemfog és első kisőrlő fog között megjelent pigmentált lézió

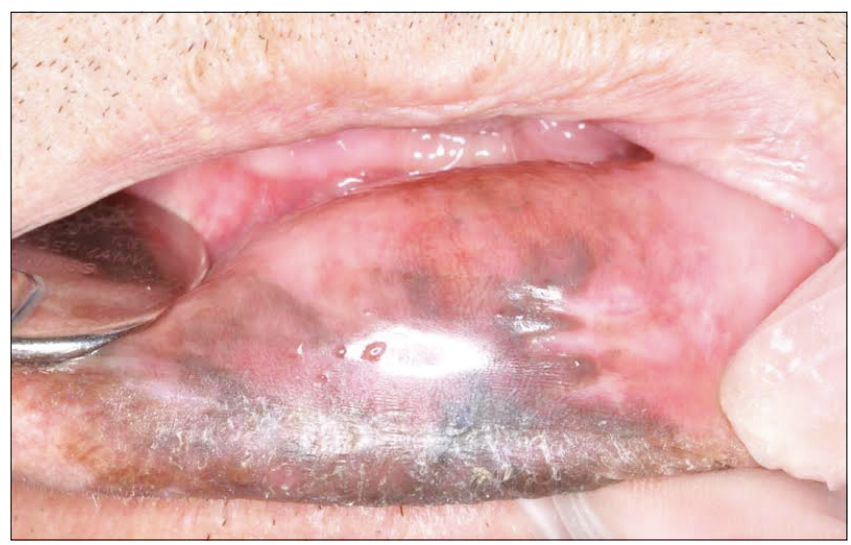

2. kép: Pigmentált elváltozás az alsó ajak orális felszínének nyálkahártyáján

metasztázis esetén szintén megfontolandó a sugárterápia, különösen, ha a metasztázisok multiplexek, nagy méretűek és a tumor extranodalis terjedése valószínüsíthető $[5,17]$.

Mivel a fej-nyak területén lévő nyálkahártya-melanoma nagyon malignus tumor, és sok páciensnél jelenik meg távoli metasztázis, ezért fontos lenne hatékony szisztémás terápia kifejlesztése az előrehaladott és inoperábilis esetekre, valamint extracapsularis terjedés esetén [5].

Előrehaladott PMM esetén, a limitált hatékonyság ellenére, a dacarbazin alapú kemoterápia standard ellátási módnak minősül [19], azonban kevésbé hatékony, mint a bőrön megjelenő típusnál [30].

A célzott immunterápia szignifikáns előnyeit az elmúlt években mutatták ki, számos új ágenst fejlesztettek ki a tumor-immunitás erősítésére. Az ipilimumab, a citotoxikus T-lymphocita antigén 4 elleni, teljesen humán, monoklonális antitest, mely immunmoduláns gyógy-

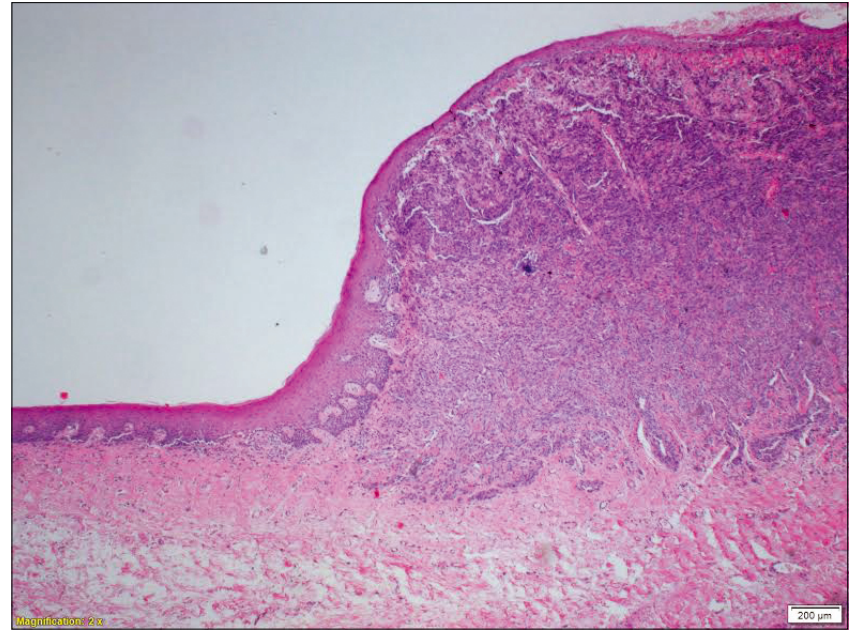

3. kép: Magas malignitású, pleiomorph, pigmenthám kiindulású invazív tumor az állcsontgerinc nyálkahártyáján (hematoxilin-eozin festés, 2x-es nagyítás)

- Kép forrása: SM-KMOK Patológia Intézet, Dr. Heckel Katalin

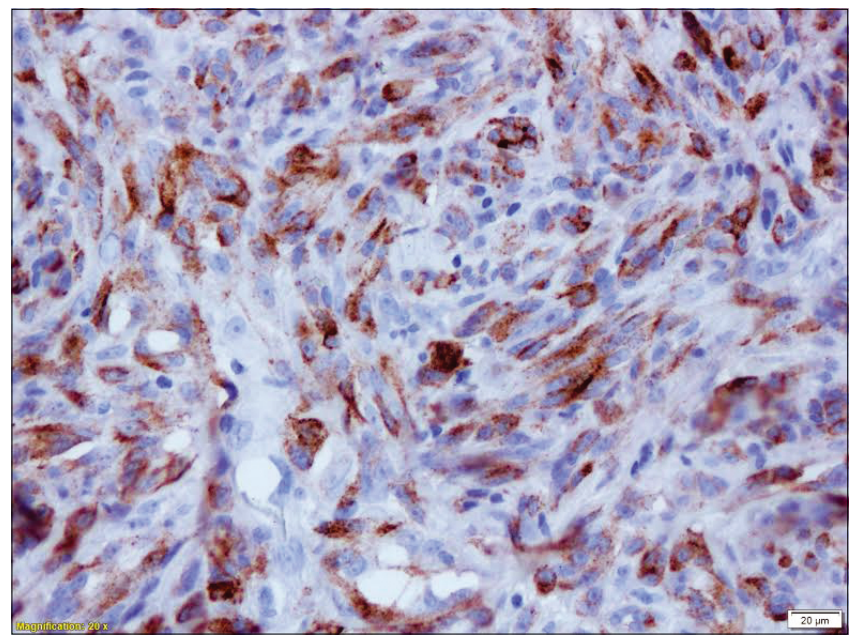

4. kép: Diffúz, közepes intenzitású cytoplazmatikus pozitivitás, HMB-45 ellenes immunreakcióval a tumort alkotó melanoblastokban (20x-os nagyítás)

- Kép forrása: SM-KMOK Patológia Intézet, Dr. Heckel Katalin

szerként használható cutan melanoma terápiájában. Postow és mtsai. PMM esetén is kimutatták az ipilimumab hatékonyságát, azonban csak csekély, mintegy $6 \%$-os válaszreakciót sikerült elérni ezen lokalizáció esetén. További kutatások szükségesek, hogy az ipilimumab és egyéb, a bőrön megjelenő melanoma célzott immunterápiájában használt immunmoduláns gyógyszerek, mint például a pembrolizumab és a nivolumab (programmed cell death-1 (PD-1) receptor elleni antitestek) PMM-ben mutatott szerepét tisztázzák [5, 20].

$\mathrm{Az}$ immunoterápia fejlődése mellett az előrehaladott mucosalis melanoma terápiája amiatt is nagy elörelépést mutat, mert sikerült megérteni egyes genetikai abnormalitásokat, amelyek a melanomák egy részénél jelentkeznek. Míg cutan melanomák esetén a BRAF 
mutáció a leggyakoribb, mucosalis melanoma esetén a receptor-tirozin kináz és a c-KIT mutat aktivációs mutációt vagy genetikai amplifikációt. Emiatt a c-KIT inhibitorok, mint az imatinib, sorafenib, dasatinib vagy a sunitinib szóba jöhetnek terápiás megoldásként nem rezekálható PMM esetén [3, 4, 5, 12, 22].

\section{Prognózis, túlélés}

Irodalmi adatok alapján, a bőrön megjelenő melanomák ötéves túlélése 80 százalék, míg húszéves túlélésük közel kétharmados. Ezzel szemben a fej-nyak területén megjelenő nyálkahártya-melanoma ötéves túlélése 11-32 százalék között mozog, közülük a szájüregben megjelenő melanomáké 15 százalék. A gingiván kialakuló melanoma csekély mértékben bár (18 százalék), de jobb túlélést mutat, mint a palatumon megjelenő típus (11 százalék). A nyirokcsomó-érintettség az orális lokalizációjú nyálkahártya-melanomák esetén 46 hónapról 18 hónapra csökkenti a túlélést. A nyálkahártyamelanoma a legmegfelelőbb terápia, azaz a megfelelő sebészi széllel elvégzett radikális rezekció ellenére is rosszabb prognózisú, mint a bőrön előforduló típus. Összefoglalásként elmondható, hogy a jelentős különbséget a bőrön megjelenő és a PMM túlélése között a malignitás késői stádiumban való felismerése, a vertikális növekedési fázis és a lézió negatív rezekciós széllel történő, adekvát eltávolításának nehézsége okozza az anatómiai lokalizáció és a létfontosságú szervek közelsége miatt. A betegség rossz prognózisáért felelős még az, hogy könnyen és korán ad áttétet, elsősorban a regionális nyirokcsomókba, majd távoli áttétként a tüdőbe, májba és intracranialisan $[7,8]$. A nyaki nyirokcsomó-áttétek az esetek 68 százalékában a submandibularis háromszögben és a felső jugularis nyirokcsomóláncban jelennek meg [31].

\section{Diszkusszió}

Az általunk a III. táblázatba foglalt öt eset különböző stádiumú és lokalizációjú melanomás esetet prezentál. A MM-ot 1859-ben Weber írta le először. A PMM definíciója Green és mtsai.-tól származik. A diagnózis akkor állítható fel, ha melanoma jelenléte észlelhető a szájüregben, fokozott a junctionalis aktivitás és extraoralis primer melanoma nem mutatható ki [1]. A betegség középkorúakban a leggyakoribb, esetünkben a betegek életkora széles skálán mozgott 35 évestôl 72 évesig. Férfiaknál gyakoribb, eseteinkben 4 női és 1 féri beteg került bemutatásra. A betegség fő lokalizációja a szájüregben a maxilláris gingiva, betegeink többségénél is itt jelentkezett a primer tumor, míg egy esetben az alsó ajkon, egy esetben a kemény és lágyszájpad határán, egy esetben pedig az orrüreg nyálkahártyáján. A fej-nyak területén megjelenő PMM ötéves túlélése 11-32 százalék között mozog, melynek fő oka a malignitás késői stádiumban történő felismerése. Betegeink közül ketten már inoperábilis stádiumban jelentkeztek. Másik három esetünk azonban, ahol a betegek rendszeres kontroll mellett képalkotó és klinikai vizsgálatok alapján jelenleg is tünet és panaszmentesek, jól példázza azt, hogy a betegség korai felismerése és adekvát terápia esetén a hosszú távú túlélés jelentősen növelhető, és sikerek érhetők el egy ilyen ritka és agresszív daganattípus esetén is.

\section{Irodalom}

1. Aquas SC, Quarracino MC, Lence AN, Lanfranchi-Tizeira HE: Primary melanoma of the oral cavity: ten cases and review of 177 cases from literature Med Oral Patol Oral Cir Bucal 2009; 14 : E 265-271

2. Ballester Sanchez R, Unamuno Bustos B, Navarro Mira M, Botella Estrada R: Mucosal melanoma: An update, Actas Dermosifiliogr. 2015; 106: 96-103

3. Curtin JA, Busam K, Pinkel D, Bastian BC: Somatic activation of KIT in distinct subtypes of melanoma. J Clin Oncol. 2006; 24: 4340-4346.

4. Curtin JA, Fridlyand J, Kageshita t, Patel hN, Busam KJ, Kutzner $\mathrm{H}$ ET AL.: Distinct sets of genetical alterations in melanoma. $N$ Engl J Med. 2005; 353: 2135-2147.

5. Fernando L, Juan PR, Antonio C, Asterios T, Kenneth O: Update on primary head and neck mucosal melanoma. Head Neck. 2016; 38: 147-155.

6. Francisco aln, Furlan MV, Peresi PM, Nishimoto IN, Lourenco SV, PINTO CAL ET AL.: Head and neck mucosal melanoma: clinicopathological analysis of 51 cases treated in a single cancer centre and review of the literature. Int J Oral Maxillofac Surg. 2016; 45: $135-140$.

7. HiCKs MJ, FLAITZ CM: Oral mucosal melanoma: epidemiology and pathobiology Review. Oral Oncol. 2000; 36: 152-169.

8. Kerr E, Bartolucci AA, Hameed O, Lewis JS, Wang D, Said-AlNAIEF: Head and neck mucosal malignant melanoma: clinicopatho-

\section{Esetismertetés}

III. táblázat

A Somogy Megyei Kaposi Mór Oktatókórházban megjelent öt mucosalis melanomás eset

\begin{tabular}{|l|c|c|l|l|}
\hline & Nem & Életkor & \multicolumn{1}{|c|}{ Lokalizáció } & \multicolumn{1}{c|}{ Szövettani diagnózis } \\
\hline 1. eset & nő & 35 & maxillaris gingiva (1. kép) & mucosalis in situ melanoma \\
\hline 2. eset & férfi & 61 & alsó ajak (2. kép) & ajakpír melanoma 0,3 mm-es Breslow vastagság, Clark II \\
\hline 3. eset & nő & 65 & maxillaris gingiva & melanoma malignum, a fogíny rosszindulatú daganata (3., 4. kép) \\
\hline 4. eset & nő & 72 & orrüreg nyálkahártya & melanoma malignum, az orrüreg rosszindulatú daganata \\
\hline 5. eset & nő & 60 & kemény-lágyszájpad határa & melanoma malignum in situ (korai radiális fázis) \\
\hline
\end{tabular}


logic correlation with contemporary review of prognostic iondicators. Int J Surg Pathol. 2012; 20: 37-46.

9. Krengli M, Masini L, KaAnders JH, Maingon P, Oei SB, Zouhair A, ET AL.: Radiotherapy in the treatment of mucosal melanoma of the upper aerodigestive tract: analysis of 74 cases. A rare cancer network study. Int J Radiat Oncol Biol Phys 2006; 65: 751-759.

10. Lu S-Y, LIN C-F, SHUN-CHEN H: Metastatic oral malignant melanoma transformed from pre-existing pigmented lesions in mandibular gingiva: Report of an unusual case. J Dent Sci., 2013 8: 328-332

11. Main BG, Coyle MJ, Godden A, Godden DR: The metastatic potencial of head and neck cutaneous malignant melanom: is sentinel biopsy useful?, B J Oral MaxillofacSurg. 2014; 52: 340-343.

12. Maldonado JL, Fridlyand J, Patel H, Jain an, Busam K, Kageshita T ET AL.: Determinants of BRAFmutations in primary melanomas. J Natl Cancer Inst. 2003; 95:1878-1890.

13. Maldonado-Mendoza J, Ramirez-Amador V, Anaya-Saavedra G, Irigoyen-Camacho M, Ruiz-Godoy EL, Ruiz-García E et al.: Clinicopathological characterization of primary oral and sinonasal melanoma in a referral centre in Mexico City: 2000-2012. Int J Oral Maxillofac Surg. 2015; 44: 427-432.

14. Mclean N, Tighiouart M, Muller S: Primary mucosal melanoma of the head and neck. Comparison of clinical presentation and histopathologic features of oral and sinonasal melanoma. Oral Oncol 2008; 44: 1039-1046.

15. Meleti M, Leemans CR, Moo WJ, Vescovi P, van der Waal I: Oral malignant melanoma: A review of the literature, Oral Oncol. 2007; 43: $116-121$.

16. Mohan M, SUKhadia VY, Pal D, BHAT S: Oral malignant melanoma: systemic review of literature and report of two cases, Int J Oral Maxillofac Surg. 2013; 116: 247-254.

17. Moreno MA, Roberts DB, Kupferman ME, DeMonte F, El-Naggar AK, WILLIAMS M. ET AL: Mucosal melanoma of the nose and paranasal sinuses, a contemporary experience from M. D. Anderson Cancer Center. Cancer 2010; 116: 2215-2223.

18. Pfister DG, Ang KK, Brizel DM, Burtness BA, Busse PM, Caudell JJ ET AL: Head and neck cancers, version 2.2013. Featured updates to the NCCN guidelines. J Natl Compr Cancer Network 2013; 11: 917-923.

19. Postow MA, Hamid O, Carvajal RD: Mucosal melanoma: pathogenezis, clinical behaviour and management. Curr Oncol Rep 2012; 14: 441-448.
20. Postow MA, Luke JJ, Bluth MJ, Ramaiya N, Panageas KS, LawRENCE DP ET AL: Ipilimumab for patients with advanced mucosal melanoma. Oncologist 2013; 18: 726-732.

21. Prasad ML, Patel SG, Huvos AG, Shah JP, Busam KJ: Primarymucosal melanoma of the head and neck: a proposal formicrostaging localized, stage I (lymph node-negative) tumors. Cancer 2004; 100:1657-64.

22. Rivera RS, Nagatsuka H, Gunduz M, Cengiz B, Gunduz E: C-KIT protein expression correlated with activating mutations in KIT gene in oral mucosal melanoma. Virchows Arch. 2008; 452: 27-32.

23. Starek I, Koranda P, Benes P: Sentinel lymph node biopsy: a new perspective in head and neck mucosal melanoma? Melanoma Res 2006; 16: 423-427.

24. Tanaka N, Amagasa T, Imaki H, Shioda S, Takeda M, Ohasi K et al: Oral malignant melanoma in Japan. Oral Surg Oral Med Oral Pathol. 1994; 78: 81.

25. Tanaka N, Mimura M, OGI K, Amagasa T: Primary malignant melanoma of the oral cavity: assessment of outcome from the clinical records of 35 patients. Int J Oral Maxillofac Surg. 2004; 33: 761-765.

26. Temam S, Mamelle G, Marandas $P$, Wibault $P$, Avril MF, Janot $F$ ET AL: Postoperative radiotherapy for primary mucosal melanoma of the head and neck Cancer, 2005; 103: 313-319.

27. UMEDA M, SHIMADA K: Primary malignant melanoma of the oral cavity - its histological classification and treatment, $B \mathrm{~J}$ Oral Maxillofac Surg. 1994; 32: 39-47.

28. Wang X, Wu, Ren GX, TANG J, Guo W: Primary oral mucosal melanoma: advocate a wait-and-see policy in the clinically NO patient. J Oral Maxillofac Surg. 2012; 70: 1192-1198.

29. Wu Y, ZHong Y, LIC, Song H, Guo W, Ren G: Neck dissection for oral mucosal melanoma: Caution of nodular lesion. Oral Oncol. 2014; 50: 319-324.

30. YI JH, Y I SY, LeE HR, LeE SI, LIm DH, KIm JH ET AL: Dacarbazinebased chemotherapy asfirst-line treatment in noncutaneous metastatic melanoma: multicenter, retrospective analysis in Asia. Melanoma Res. 2011; 21: 223-227.

31. Yunteng W, Yi Z, Chaojun L, Hao S, Wei G, Guoxin R: Neck dissection for oral mucosal melanoma: Caution of nodular lesion. Oral Oncol. 2014; 50: 319-324.

\section{Kiss F, Fülöp G, Oberna F, Battyánı Z}

\section{Head and neck mucosal melanoma: clinicopathological analysis of 5 cases and review of the literature}

Mucosal melanoma in the region of head and neck is a rare and aggressive tumor. Diagnosis is usually late due to the quick, vertical spread of the disease, the a lack of early or specific signs and because of the location of lesions. The mainstay of treatment is radical surgical resection. The value of sentinel lymph node biopsy, lymphadenectomy and radiotherapy is still unclear. The objective of this study is to report five patients with primer malignant mucosal melanoma and briefly summarize the current literature of the etiology, staging and treatment of the disease.

Keywords: head and neck, mucosal melanoma, diagnosis, staging, radical surgical resection 